\title{
A cytogenetic study of men occupationally exposed to uranium
}

\author{
Fiona Martin, R Earl, E Janet Tawn
}

\begin{abstract}
Blood lymphocyte cultures from two groups of workers occupationally exposed to uranium were examined for asymmetrical chromosome aberrations and sister chromatid exchanges (SCEs). Significant increases in both cytogenetic endpoints were seen. For dicentrics this appeared to be particularly associated with exposure to soluble uranium. The external radiation exposure experienced by these men was insufficient to explain the increase in dicentrics, and irradiation of lymphocytes by internally deposited uranium would have been minimal. As the SCEs were also raised, the genotoxic effect is likely to be due to the chemical nature of the compound. The increase in frequency of dicentrics associated with smoking was greatest in the group with exposure to soluble uranium suggesting some interaction between the two clastogens. No such interactive effect was seen for SCE frequencies, in which increases attributable to smoking were similar in the worker and control groups.
\end{abstract}

Chromosome aberration analysis is recognised as a useful monitor of exposure to external radiation in the nuclear industry. Frequencies of aberrations resulting from exposure to internally deposited $\alpha$ emitters, however, can be more difficult to interpret due to the non-uniform distribution of the radioactive material and the limited range of the particles. For the study of chemical exposures a different technique, sister chromatid exchange (SCE) analysis, is usually employed.

As SCEs and chromosome aberrations arise from different responses to DNA lesions, the study of both endpoints provides complementary information on exposure to mutagens. The incorporation of radionuclides into the body, as well as being a potential radiological hazard, may have a genotoxicological

Geoffrey Schofield Cytogenetics Laboratory, British Nuclear Fuels Plc, Sellafield, Seascale, Cumbria A20 1PG

F Martin, R Earl, E J Tawn effect related to the chemical nature of the compound. Measurement of both SCEs and chromosome aberrations were therefore used in this study of workers occupationally exposed to uranium.

Natural uranium consists of a mixture of isotopes, and is a valuable resource for nuclear power production. The main radioactive emission is $\alpha$. The processing and enrichment of uranium to produce fuel for nuclear reactors encompasses a variety of chemical processes and results in a range of potential types of chemical and radiological exposure.

The metabolism of uranium has been extensively reviewed. ${ }^{12}$ Long term retention is primarily in the bone, but after administration, high concentrations of uranium first occur in the kidneys. This is particularly true for soluble uranium, which is easily absorbed into the blood. Work with laboratory animals has shown that fatal doses to the kidney are much lower than those expected to produce radiation effects in bone, and therefore the toxicological hazard to the kidneys is considered the limiting factor when setting dose limits for chronic exposure. Effects of radiation may become significant for inhaled uranium particularly if the material is insoluble and is retained in the lungs.

Cytogenetic studies of workers occupationally exposed to uranium have been limited, and mainly confined to uranium miners. ${ }^{3-6}$ Increased frequencies of chromosome aberrations have been shown in most of these reports. In uranium mines the main exposure is to radon and its daughter products and the results are therefore not directly comparable to the exposure to uranium encountered during production of nuclear fuel.

\section{Methods}

Two groups of uranium workers were studied. The first, group A, comprised 20 men from a fuel production plant with a wide range of exposures to soluble and insoluble uranium. The second group of 73 men, group B, worked in a fuel enrichment plant where the exposure was confined to soluble $U_{6}$. Twenty non-radiation workers matched for age and smoking habits with group $A$ and sampled at the same time formed control group C. Frequencies of chromosome aberrations were also compared with a larger group (D) of 66 historical controls from our laboratory. ${ }^{7}$ As frequencies of SCEs can be influen- 
ced by culture conditions, ${ }^{8}$ historical controls are not applicable and only group $\mathrm{C}$ was used as the control frequencies for comparisons of SCE frequencies.

External $\gamma$-radiation doses were recorded by film badges and other monitoring devices. Estimates of lung dose due to uranium were calculated from air sampling, faecal and urine analysis, and whole body monitoring. All the men had exposures well within the International Commission on Radiological Protection limits.

Peripheral blood lymphocytes were cultured with Eagle's minimum essential medium containing $15 \%$ fetal bovine serum and $7 \cdot 2 \mu \mathrm{M}$ bromodeoxyuridine. Cultures were stimulated with phytohaemagglutinin and colcemid was added four hours before harvesting. The slides were stained by a modification of the fluorescence plus Giemsa method of Perry and Wolff. ${ }^{9}$ Two hundred first division cells from each member of groups A, B, and C and 100 from group D were scored from 48 hour cultures for asymmetrical chromosome aberrations and chromatid exchanges. Thirty second division cells from each subject were scored from 72 hour cultures for SCEs for all those in groups $A$ and $C$. This was only possible for 50 men in group B.

\section{Results and discussion}

EXPOSURE TO URANIUM

Both groups of uranium workers (A and B) had higher levels of chromosome aberrations than the controls (C and D) (table 1). The two control groups had similar frequencies of dicentrics and these were comparable with previously reported background values (for review see Tawn and Cartmell $^{10}$ ). Frequencies of chromatid exchanges were also similar but the frequency of acentrics was higher in group $C$ than in group $D$.

In group $A$ the frequency of dicentrics was higher than for the matched control group $\mathrm{C}$ although the threefold increase did not reach statistical significance. The frequency of acentrics was also higher, and significance was reached when all the asymmetrical chromosome aberrations were included $\left(\chi_{1}^{2}=6 \cdot 15, \mathrm{p}<0.05\right)$. No chromatid exchanges were found in this group.

Most men in group A had been radiation workers for more than 20 years during which a range of external radiation doses had been accumulated, albeit at dose rates of less than $10 \mathrm{mSv}$ a year. The mean total dose to the group would, if received as an acute dose, result in an increase in frequency of dicentrics but with a chronic dose some loss of lymphocytes carrying dicentrics will have occurred over the years. To adjust for this, yearly radiation doses were weighted for a three year half life and added together to obtain an equivalent acute dose at the time of blood sampling. ${ }^{11}$ The group mean of these adjusted doses was $16.8 \mathrm{mSv}$. A theoretical estimate, based on published data, ${ }^{12}$ suggests that an external acute dose of $16.8 \mathrm{mSv}$ would contribute less than $20 \%$ of the dicentrics seen in group A. If this contribution from external radiation is subtracted, the frequency

Table 1 Group data on age, smoking, radiation exposure, and aberration frequencies

\begin{tabular}{|c|c|c|c|c|}
\hline & Group $A$ & Group B & Group $C$ & Group D \\
\hline $\begin{array}{l}\text { No of men } \\
\text { Mean age }(\mathrm{y}) \text { (range) } \\
\text { Smokers }(\%) \\
\text { Mean total external dose }(\mathrm{mSv})(\text { range }) \\
\text { Mean lung dose from uranium }(\mathrm{mSv})(\text { range) } \\
\text { No of cells } \\
\text { No of dicentrics }(+ \text { centric rings) } \\
\text { Dicentrics }(\mathrm{SE}) \times 10^{-3} / \text { cell } \\
\text { No of acentrics } \\
\text { Acentrics }(\mathrm{SE}) \times 10^{-3} / \text { cell } \\
\text { Total No of chromosome aberrations } \\
\text { Total aberrations }(\mathrm{SE}) \times 10^{-3} / \text { cell } \\
\text { No of chromatid exchanges } \\
\text { Chromatid exchanges }(\mathrm{SE}) \times 10^{-3} / \text { cell }\end{array}$ & $\begin{array}{l}20 \\
52(33-62) \\
35 \\
134 \cdot 2(0 \cdot 0-485 \cdot 0) \\
171 \cdot 8(0 \cdot 0-1048 \cdot 0) \\
4000 \\
6(+1) \\
1.50(0 \cdot 61) \\
25 \\
6 \cdot 25(1 \cdot 25) \\
32 \\
8.00(1 \cdot 41) \\
0 \\
0.00\end{array}$ & $\begin{array}{l}73 \\
43(25-64) \\
53 \\
6 \cdot 8(0 \cdot 0-44 \cdot 7) \\
117 \cdot 1(0 \cdot 0-360 \cdot 0) \\
14600 \\
38(+3) \\
2 \cdot 60(0 \cdot 42) \\
50 \\
3 \cdot 42(0 \cdot 48) \\
91 \\
6 \cdot 23(0 \cdot 65) \\
9 \\
0.62(0 \cdot 21)\end{array}$ & $\begin{array}{l}20 \\
52(34-62) \\
35 \\
- \\
4000 \\
2 \\
0.50(0.35) \\
13 \\
3 \cdot 25(0.90) \\
15 \\
3.75(0.97) \\
3 \\
0.75(0.43)\end{array}$ & $\begin{array}{l}66 \\
40(27-59) \\
33 \\
- \\
- \\
6600 \\
4(+1) \\
0.61(0.30) \\
14 \\
2 \cdot 12(0.57) \\
19 \\
2.88(0.66) \\
5 \\
0.76(0.34)\end{array}$ \\
\hline
\end{tabular}

Table 2 Group data on age, smoking, radiation exposure, and SCE frequencies

\begin{tabular}{|c|c|c|c|}
\hline & Group $A$ & Group B & Group C \\
\hline $\begin{array}{l}\text { No of men } \\
\text { Mean age (y) (range) } \\
\text { Smokers }(\%) \\
\text { Mean total external dose (mSv) (range) } \\
\text { Mean lung dose from uranium (mSv) (range) } \\
\text { Mean SCEs/cell (SD) } \\
\quad \text { (range) }\end{array}$ & $\begin{array}{l}20 \\
52(33-62) \\
35 \\
134 \cdot 2(0 \cdot 0-485 \cdot 0) \\
171 \cdot 8(0 \cdot 0-1048 \cdot 0) \\
9 \cdot 3(0 \cdot 4) \\
(6 \cdot 3-11 \cdot 8)\end{array}$ & $\begin{array}{l}50 \\
44(25-62) \\
50 \\
6 \cdot 8(0 \cdot 0-44 \cdot 7) \\
92 \cdot 5(0 \cdot 0-360 \cdot 0) \\
9 \cdot 9(0 \cdot 3) \\
(7 \cdot 1-14 \cdot 0)\end{array}$ & $\begin{array}{l}20 \\
52(34-62) \\
35 \\
- \\
7 \cdot 3(0 \cdot 4) \\
(6 \cdot 0-10 \cdot 8)\end{array}$ \\
\hline
\end{tabular}


Table 3 Aberration frequencies in smokers and non-smokers

\begin{tabular}{|c|c|c|c|}
\hline & \multicolumn{2}{|l|}{ Group $A$} & \multirow{2}{*}{$\frac{\text { Group B }}{\text { Non-smokers }}$} \\
\hline & Non-smokers & Smokers & \\
\hline $\begin{array}{l}\text { No of men } \\
\text { Mean age }(y) \text { (range) } \\
\% \text { Smokers }>20 \text { cigarettes } / \text { day } \\
\text { Mean total external dose }(\mathrm{mSv})(\mathrm{range}) \\
\text { Mean lung dose from uranium }(\mathrm{mSv})(\text { range) } \\
\text { No of cells } \\
\text { No of dicentrics }(+ \text { centric rings) } \\
\text { Dicentrics }(\mathrm{SE}) \times 10^{-3} / \text { cell } \\
\text { No of acentrics } \\
\text { Acentrics }(\mathrm{SE}) \times 10^{-3} / \text { cell } \\
\text { Total No of chromosome aberrations } \\
\text { Total chromosome aberrations }(\mathrm{SE}) \times 10^{-3} / \text { cell } \\
\text { No of chromatid exchanges } \\
\text { Chromatid exchanges }(\mathrm{SE}) \times 10^{-3} / \text { cell }\end{array}$ & $\begin{array}{l}13 \\
50(33-62) \\
94 \cdot 7(0 \cdot 0-203 \cdot 0) \\
195 \cdot 8(0 \cdot 0-1048 \cdot 0) \\
2600 \\
3 \\
1 \cdot 15(0 \cdot 67) \\
14 \\
5 \cdot 38(1 \cdot 44) \\
17 \\
6 \cdot 54(1 \cdot 59) \\
0 \\
0.00\end{array}$ & $\begin{array}{l}7 \\
57(52-61) \\
30 \\
207 \cdot 4(102 \cdot 0-485 \cdot 0) \\
127 \cdot 0(13 \cdot 0-534 \cdot 0) \\
1400 \\
3(+1) \\
2 \cdot 14(1 \cdot 24) \\
11 \\
7 \cdot 86(2 \cdot 37) \\
15 \\
10 \cdot 71(2 \cdot 77) \\
0 \\
0 \cdot 00\end{array}$ & $\begin{array}{l}34 \\
42(25-64) \\
6 \cdot 6(0 \cdot 0-44 \cdot 7) \\
98 \cdot 7(20 \cdot 0-252 \cdot 0) \\
6800 \\
11(+2) \\
1.62(0 \cdot 49) \\
20 \\
2.94(0.66) \\
33 \\
4.85(0.84) \\
2 \\
0.29(0.21)\end{array}$ \\
\hline
\end{tabular}

of dicentrics is still 2.5 times higher than that in group C.

Frequencies of dicentrics and total chromosome aberrations were significantly higher in group B of uranium workers than in the control group $\mathrm{D}\left(\chi_{1}^{2}=\right.$ $9.15, \mathrm{p}<0.005$ and $\left.\chi_{1}^{2}=9.86, \mathrm{p}<0.005\right)$, the frequency of dicentrics being four times that of the control. The frequencies of chromatid exchanges, however, were similar to controls. The mean total external dose was $6.8 \mathrm{mSv}$ for group B, which, even if obtained as an acute dose, would not result in a detectable increase in frequency of dicentrics.

Although the external radiation exposure was greater in group A than group B, it was group B that had the highest level of dicentrics. In group B exposure was to soluble uranium, whereas in group $A$ a range of different types of exposure had occurred. Subdivision of group A showed that four of the six dicentrics were present in the four men with exposure to soluble uranium. The frequency of dicentrics in the remainder of group A was comparable with that of the controls. The frequencies of acentrics were similar in the two subgroups.

Chronic exposure to uranium results in radiation doses to the lung (table 1); however, uranium deposited in the lung is unlikely to irradiate the peripheral blood lymphocytes because of the short range of $\alpha$-irradiation. There will be some transport of inhaled uranium, particularly soluble types, via the blood to the kidneys and sites of long term deposition but the resulting radiation doses to the lymphocytes will be negligible.

Frequencies of SCEs were increased in both groups of uranium workers compared with the control group C (group A: $t_{38}=4.4, p<0.001$; group B: $\left.t_{68}=5 \cdot 7, \mathrm{p}<0.001\right)$ with the highest frequency occurring in group B (table 2). On subdivision of group A similar frequencies of SCEs were found in the four men with soluble exposure compared with the rest of the group.

Occupational exposure to a range of chemicals has been shown to increase the frequency of SCEs in lymphocytes in peripheral blood. ${ }^{13}$ By contrast, ionising radiations are generally thought to be poor inducers of SCEs although recent work in vitro has suggested that exposure to $\alpha$-irradiation can result in a significant increase. ${ }^{14}$ The exposure conditions in that study, however, enabled all the cells to be irradiated by $\alpha$-particles. In the peripheral blood of the uranium workers only an extremely small proportion of the lymphocytes are going to be hit by an $\alpha$-particle and not all of these will survive to second division in culture to be analysed.

This study indicates that a genotoxic effect is seen in men occupationally exposed to uranium and the results for dicentrics suggest that this may particularly apply to exposure to the soluble form. This effect is unlikely to be directly due to radiation and probably results from chemical interactions in the cell.

\section{EFFECT OF SMOKING}

In the uranium worker groups (A and B) and the larger control group D, higher frequencies of dicentrics and acentrics were seen in the smokers compared with the non-smokers (table 3). In group C only the frequency of acentrics was higher. The increase in dicentrics in smokers was greater in the uranium worker groups than the controls and reached significance for group $B\left(\chi_{1}^{2}=4.75, \mathrm{p}<0.05\right)$. The size of this group allowed subdivision according to smoking habits and showed that even the moderate to light smoking group exhibited a frequency of dicentrics greater than the non-smoking value (table 4).

We have previously identified a significant effect of heavy smoking on dicentric yield in both nonirradiated controls ${ }^{715}$ and radiation workers, ${ }^{15}$ but have found it difficult to establish a significant effect of moderate or light smoking. Although a smoking effect on frequency of dicentrics has been reported, not all studies have been able to show raised levels. 


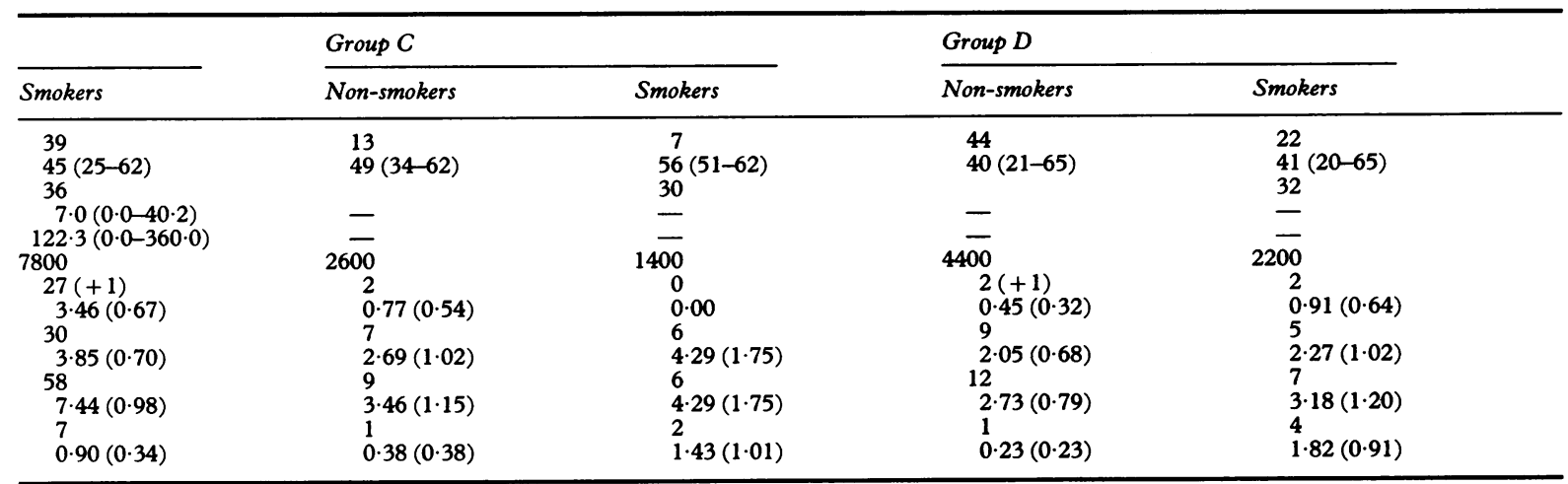

Table 4 Dicentric frequencies and smoking habits of group $B$

\begin{tabular}{llll}
\hline Smoking state & $\begin{array}{l}\text { No of } \\
\text { men }\end{array}$ & $\begin{array}{l}\text { No of } \\
\text { dicentrics }\end{array}$ & $\begin{array}{l}\text { Dicentrics } / \\
\text { cell }(S E) \times 10^{-3}\end{array}$ \\
\hline Cigarettes: & & & \\
Heavy $(>20 /$ day $)$ & 14 & 10 & $3.57(1.13)$ \\
Light $(<20 /$ day $)$ & 17 & 9 & $2.65(0.88)$ \\
Pipe and cigars & 8 & 8 & $5.00(1 \cdot 77)$ \\
Total No of smokers & 39 & 27 & $3.46(0.67)$ \\
No of non-smokers & 34 & 11 & $1.62(0.49)$ \\
\hline
\end{tabular}

Differences in smoking profiles between studies, however, make direct comparisons difficult (for review see Tawn and Cartmell $\left.{ }^{10}\right)$. When dealing with aberrations with a low frequency, the study group has to be large. Group C illustrates this problem; only two dicentrics were found for the group as a whole, both in the larger subgroup of non-smokers.

The difference in the smoking effect between the two uranium worker groups can possibly be attributed to the different types of exposure. In group B, exposure was to soluble $\mathrm{UF}_{6}$ but in group $\mathrm{A}$ exposure was more heterogeneous with only four men having an exposure comparable with group B. As already discussed, four of the six dicentrics occurred in this subgroup, and it is notable that two of these were in the only subject who smoked.

In view of the high frequency of dicentrics found in the uranium workers who smoked, the possibility of some interaction between exposure to uranium and smoking needs further investigation. This is particularly important in view of the known association of smoking with lung cancer and the suggestion of an increase in the incidence of lung cancer in uranium processing workers. ${ }^{16}$

Examination of the distribution of the dicentrics amongst the cells in group B showed that the 11 dicentrics in the non-smokers occurred in separate cells but the 23 dicentrics in the smokers were overdispersed. One cell contained two dicentrics and two cells contained three. The numbers in group A were small but it is of interest that the two dicentrics in the smoker with exposure to soluble uranium occurred in one cell whereas the rest were in separate cells. This raises the question as to whether a special subset of cells exists in smokers that is more susceptible to chromosome damage by uranium.

Significant increases in frequencies of SCEs attributable to smoking were seen in both the uranium worker groups A and B $\left(t_{15}=2.3, \mathrm{p}<0.05\right.$ and $\left.t_{45}=3.7, \mathrm{p}<0.001\right)$ and in the control group $\mathrm{C}$ $\left(t_{15}=2.8, \mathrm{p}<0.01\right)$ (table 5). This increase accords with the well documented effect of cigarette smoking on frequencies of SCEs. ${ }^{17}$ A breakdown of group B (table 6) showed that a higher frequency of SCEs occurred in the heavy smokers than in the moderate

Table 5 SCE frequencies in smokers and non-smokers

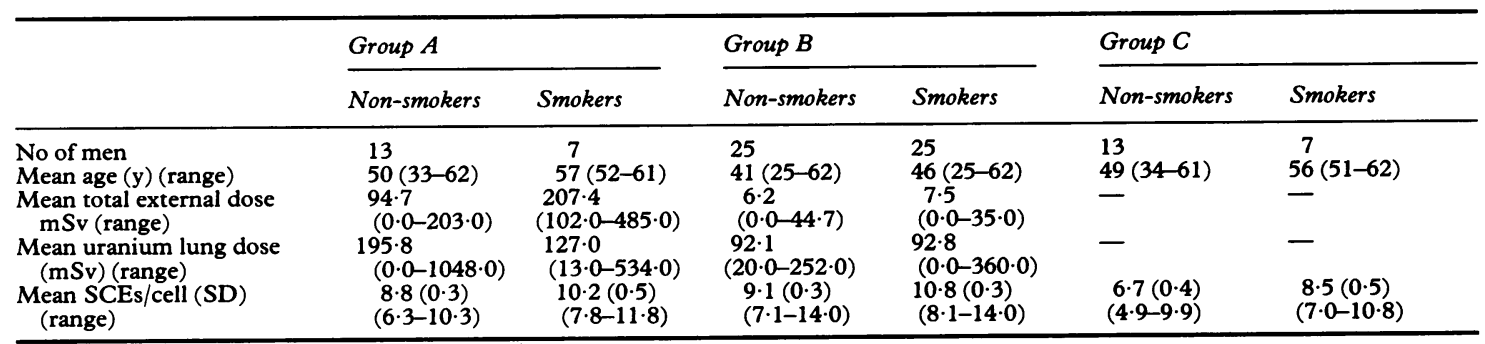


Table 6 SCE frequencies and smoking habits of group $B$

\begin{tabular}{lcl}
\hline Smoking state & $\begin{array}{l}\text { No of } \\
\text { men }\end{array}$ & $\begin{array}{l}\text { SCE/cell } \\
(S D)\end{array}$ \\
\hline Cigarettes: & & \\
Heavy $(>20 /$ day) & 6 & $11.9(0.5)$ \\
Light $(<20 /$ day) & 13 & $10 \cdot 5(0.5)$ \\
Pipe and cigars & 6 & $10 \cdot 3(0 \cdot 7)$ \\
Total No of smokers & 25 & $10 \cdot 8(0.3)$ \\
No of non-smokers & 25 & $9 \cdot 1(0.3)$ \\
\hline
\end{tabular}

to light smokers but, by contrast with the findings for dicentrics, the pipe plus cigar group had the lowest value. The increases in SCEs in the uranium worker groups were similar to those of the control group, suggesting that for this type of cytogenetic endpoint no interaction exists between smoking and exposure to uranium. This is not surprising as SCEs and chromosome aberrations are derived from different types of DNA lesion.

1 Bernard SR. Maximum permissible amounts of natural uranium in the body, air and drinking water based on human experimental data. Health Phys 1958;1:288-305.

2 Wrenn ME, Durbin PW, Howard B, et al. Metabolism of ingested $U$ and Ra. Health Phys 1985;48:601-33.

3 Kilibarda M, Markovic B, Panov D. Chromosome aberrations in irradiated persons. Studia Biophysica 1968;6:179-86.

4 Macdiarmid WD, Matthies A, Trapp EF, Babcock JR, Tyler $\mathrm{FH}$. Chromosomal changes produced by irradiation in uranium miners. Mammalian Chromosome Newsletter 1968;9:36.
5 Brandom WF, Saccomanno G, Archer VE, Archer PG, Coors $M$. Chromosome aberrations in uranium miners occupationally exposed to ${ }^{222}$ radon. Radiat Res 1972;52:204-15.

6 Saccomanno G, Archer VE, Archer PG, Bloom A. Chromosome aberrations as a biological dose-response indicator of radiation exposure in uranium miners. Radiat Res 1978;76:159-71.

7 Tawn EJ. The frequency of chromosome aberrations in a control population. Mutat Res 1987;182:303-8.

8 Lamberti L, Ponzetto PB, Ardito G. Cell kinetics and sisterchromatid-exchange frequency in human lymphocytes. Mutat Res 1983;120:193-9.

9 Perry P, Wolff S. New giemsa method for the differential staining of sister chromatids. Nature 1974;251:156-8.

10 Tawn EJ, Cartmell CL. The effect of smoking on the frequencies of asymmetrical and symmetrical chromosome exchanges in human lymphocytes. Mutat Res 1989;224:151-6.

11 Lloyd DC, Purrott RJ, Reeder EJ. The incidence of unstable chromosome aberrations in peripheral blood lymphocytes from unirradiated and occupationally exposed people. Mutat Res 1980;72:523-32.

12 Lloyd DC, Edwards AA, Prosser JS. Chromosome aberrations induced in human lymphocytes by in vitro acute $\mathrm{X}$ and gamma radiation. Radiation Protection Dosimetry 1986;15:83-8.

13 Perry P, Evans HJ. Cytological detection of mutagen-carcinogen exposure by sister chromatid exchange. Nature 1975;258: $121-5$.

14 Aghamohammadi SZ, Goodhead DT, Savage JRK. Induction of sister chromatid exchanges (SCE) in $G_{0}$ lymphocytes by plutonium $^{238} \alpha$-particles. Int $J$ Radiat Biol 1988;53: 909-15.

15 Tawn EJ, Binks K. A cytogenetic study of radiation workers: the influence of dose accumulation patterns and smoking. Radiation Protection Dosimetry 1989;28:173-80.

16 Polednak AP, Frome EL. Mortality among men employed between 1943 and 1947 at a uranium-processing plant. JOccup Med 1981;23:169-78.

17 Bender MA, Preston RJ, Leonard RC, Pyatt BE, Gooch PC, Shelby MD. Chromosomal aberration and sister-chromatid exchange frequencies in peripheral blood lymphocytes of a large human population sample. Mutat Res 1988;204:421-33.

Accepted 20 August 1990 